\title{
Medication reconciliation as a strategy for preventing medication errors
}

\author{
Luana de Rezende Spalla, Selma Rodrigues de Castilho*
}

\author{
Pharmacy and Pharmaceutical Management Department, Pharmacy School, Fluminense Federal University, \\ Niterói, RJ, Brazil
}

\begin{abstract}
One of the current barriers proposed to avoid possible medication errors, and consequently harm to patients, is the medication reconciliation, a process in which drugs used by patients prior to hospitalization can be compared with those prescribed in the hospital. This study describes the results of a pharmacist based reconciliation conducted during six months in clinical units of a university hospital. Fourteen patients $(23.33 \%)$ had some kind of problem related to medicine. The majority $(80 \%)$ of medication errors were due to medication omission. Pharmaceutical interventions acceptance level was $90 \%$. The results suggest that pharmacists based reconciliation can have a relevant role in preventing medication errors and adverse events. Moreover, the detailed interview, conducted by the pharmacist, is able to rescue important information regarding the use of drugs, allowing to avoid medications errors and patient injury.
\end{abstract}

Uniterms: Medication reconciliation. Medications/errors/ion Medications/adverse events/prevention. Patient safety. Pharmacist/professional performance.

\begin{abstract}
Uma das barreiras propostas para se evitar possíveis erros relacionados a medicamentos e, consequentemente, que danos acometam o paciente, é a reconciliação medicamentosa no ato da internação, processo no qual se comparam os medicamentos usados pelos pacientes previamente à internação com os prescritos no âmbito hospitalar. Este trabalho descreve os resultados de seis meses de um processo de reconciliação conduzido por farmacêutico em unidades clínicas de um hospital universitário. Quatorze pacientes $(23.33 \%)$ tiveram algum tipo de problema relacionado ao uso de medicamentos. A maioria dos erros envolvendo medicamentos (80\%) estava relacionada à omissão de medicamentos. As intervenções farmacêuticas tiveram $90 \%$ de aceitação pelos médicos. Os resultados sugerem que a atuação de farmacêuticos na reconciliação medicamentosa pode desempenhar papel relevante na prevenção de erros de medicamentos e eventos adversos. Além disso, a entrevista detalhada conduzida por um farmacêutico se mostrou capaz de resgatar informações importantes sobre o uso dos medicamentos, permitindo evitar erros e danos ao paciente.
\end{abstract}

Unitermos: Reconciliação medicamentosa. Medicação/erros/prevenção. Medicação/eventos adversos/ prevenção. Paciente/segurança. Farmacêutico/atuação profissional.

\section{INTRODUCTION}

Health care innovations, including new medicines, have been providing improvements in the quality and life expectancy of thousands of people, but also make the health care process increasingly expensive and complex (Rosa, Perini, 2003; Chambers et al., 2014). In addition,

\footnotetext{
*Correspondence: S. R. de Castilho. Departamento de Farmácia e Administracão Farmacêutica. Faculdade de Farmácia. Universidade Federal Fluminense - UFF. Rua Dr. Mário Viana, 523, Santa Rosa, 24241-000 - Niterói - RJ, Brasil. E-mail: selmarc@id.uff.br
}

drug use safety concept is also changing as there involves the knowledge in pharmacology, health care safety and many other areas of knowledge (Rosa, Perini, 2003; Gottlieb, 2007), demanding actions to assure the best benefits with lower risk of harm to patients (Moran, Scanlon, 2013).

In this scenario, the safe use of medicines became one of the most significant challenges to be faced by all the health care stakeholders, including scientific societies, health organizations and hospitals around the world (Moran, Scanlon, 2013). 
Since 1990s, many publications contributed to the knowledge and awareness of the importance of medication errors (Hartwig et al., 1991; Leape et al., 1991; Kohn et al., 2001; Otero et al., 2002; Rosa, Perini, 2003; WHO, 2007; Smith et al., 2014; Call et al., 2014). From then on, researchers in the health field focused their attention to this problem, previously unnoticed in everyday of health professionals that deal with medicine use.

A medication error can be defined as any error that occurs within the medication use process (Otero et al., 2002). The National Coordinating Council for Medication Error Reporting and Prevention (NCCMERP, 2014) describes it as "any incident, which can be prevented, which can cause harm to the patient or lead to inappropriate use of drugs, when they are beyond the control of the health professionals, the patient or the consumer".

It is estimated that the damage caused by medication errors affects 1.5 million people each year in the U.S., and thousands of them die (WHO, 2007). In some countries more than $67 \%$ of prescriptions have one or more errors at different times during patient care, with prevalence in hospitalized patients (WHO, 2007).

A retrospective study including all hospital admissions of adults in medical and surgical clinics in Brazil, in 2007, showed 3.6 potential adverse events per 1,000 admissions, with a greater frequency in medical clinics $(5.3$ per 1,000$)$. Besides the harm to the patient, these events were also associated with increased health expenditures, days of hospital stay and mortality (Dias et al., 2012).

In Brazil, a multicenter study in clinical units of five hospitals showed 1,500 errors among 4,958 drug administration observations (30.24\%). Among those errors, $277(18.5 \%)$ were related to antimicrobial agents (Marques et al., 2008).

Despite the growing number in recent years, there are still few studies both on drug related adverse events and on understanding and evaluating the magnitude and the impact generated by adverse events in health care institutions in Brazil (Gallotti, 2003; Mendes et al., 2008; Marques et al., 2008; Rozenfeld et al., 2009, Giordani, Rozenfeld, 2009; Reis, Cassiani, 2011; Giordani et al., 2012; Roque et al., 2012; Ventura et al., 2012; Dias et al., 2012; Rozenfeld, Giordani, 2013; Mendes et al., 2013).

Medication errors' reduction should permeate planned and systematic preventive measures. A systematic approach is based on the central idea that it is necessary to change health professionals' working conditions through deployment of defense mechanisms, barriers and protections in the organizational system. When a system fails, multiple errors occurred simultaneously, interrelated, unexpectedly, what creates a chain of events in which errors grow and evolve, resulting in an accident. The errors that occur in this chain are potentially harmful to the patient. Therefore, should be prevented, avoided, and corrected.

Medication reconciliation is one of the barriers proposed to reduce medication errors in health care transitions (Chhabra et al.,2011; Knez et al., 2011; Hellstrom et al., 2012). It is a formal process of continuous care that consists of three steps for gathering data: check (patient medication history), clarification (confirmation if the doses, dosages and instructions on medicines are used correctly by the user) and the reconciliation itself (documentation of changes and requirements) (Chhabra et al., 2011).

The importance of medication reconciliation resides in the fact that preventable adverse drug events (ADE) at transition points of care account for $46-56 \%$ of all medication errors (Chhabra et al., 2011). Omission of medications previously used by patients accounts for $42 \%$ to $60 \%$ of those errors, both at admission and at discharge, followed by differences in dose, frequency, time, route and form of administration. The reconciliation process is associated with $43 \%$ prevention of adverse events and medication errors on admission (Boockvar et al., 2011).

A drug discrepancy can involve omission of any medication (any item not prescribed), extra medication, unnecessarily prescribed, high or low doses or wrong medication dosage form (Hellstrom et al., 2012). About $22 \%$ of drug discrepancies can cause harm to the patient during hospitalization, and $59 \%$ of them may remain after discharge (Boockvar et al., 2011). Studies have reported the frequency and consequences of discrepancies in treatments, and some authors pointed out that more than $50 \%$ of the patients had at least one discrepancy not justified at admission (Cornish et al., 2005).

It has been shown that pharmacists can contribute in improving the quality and safety of medication use during in patients' care, through medication reconciliation strategies (Vira et al., 2006; Lubowski et al., 2007; Cobaugh et al.,2008; Pippins et al., 2008; Coffey et al., 2009; Stone et al., 2010; Miranda et al., 2012; Chhabra et al., 2012).

The objective of this study was to evaluate a pharmacist driven medication reconciliation at hospital admission as a tool in the prevention of medication errors.

\section{MATERIAL AND METHODS}

The study was conducted at a University hospital in the city of Niterói. This hospital is the reference in the 
Metropolitan Region II in Rio de Janeiro state. It covers more than 2 million people who reside in the cities of Niterói, São Gonçalo, Itaboraí, Rio Bonito, Marica, Silva Jardim and Tanguá.

For six months, from January to June 2012, a prospective study involving the Medication Reconciliation with inpatient, in female and male Medical Clinic units, was performed. Those clinics meet the following specialties: dermatology, endocrinology, nephrology, pulmonology, medical clinic, gastroenterology, neurology and cardiology.

All the patients admitted both through emergency care or elective procedures among the various specialties, 18 years or older, were invited to participate at the study. Only non-responsive and psychiatric patients were excluded from the study. Each patient was contacted and interviewed by the pharmacist within 48 hours after admission. The data relating to patients and medications used were recorded in the appropriate form.

The list of medications taken by the patient prior to hospital admission, collected by the pharmacist, was compared to the patient prescription upon admission. Medical records and prescriptions were also analyzed during the medication reconciliation.

When observed some discrepancy as omission of any medicine, diverging dose from usual or drug interaction, the clinical team was contacted and the case discussed with those responsible for the patient. For each contact the acceptance of the pharmaceutical intervention proposal was registered. The potential for harm to the patient of the observed error was also discussed with the health care team. No intervention or amendment were performed without the clinical team consent, which was completely free to deny the suggestion made.

The Medication Errors found were classified according to the National Coordinating Council for Medication Error Reporting and Prevention (NCCMERP, 2012). The doses above the daily maximum permitted or under dosing were determined by the hospital clinical protocols and recognized references in the field (ASHP, 2012; Thomson, 2012). Differences between the dose prescribed and the dose reported by the patient were also considered. It was considered that any discrepancies were unintentional, and all of them were discussed with the health care team.

Data were tabulated in a Microsoft Excel ${ }^{\circledR}$ spreadsheet. For establish the drug use profile and types of medication errors, as well as pharmaceutical interventions and grade of acceptance, descriptive statistic was applied. To identify variables that could be considered risk factors for the occurrence of problems, statistical tests were performed with a confidence interval of $95 \%$ and a significance level of $\mathrm{p}$-value $\leq 0,05$. The numeric variables (number of medications taken and patients' age) were analyzed through t-Student test. For the analysis of dichotomous variables (day or night admission, emergency or elective admission) the chi-square test was applied. Those analyzes were performed using S-Plus 8.0 software.

For medications classification the ATC (Anatomical Therapeutic Chemical Classification) classification, as recommended by the World Health Organization (WHO), was used.

The research was conducted within the ethical standards and approved by the ethics committee according to the Resolution 196/96 from CNS (CEP-CMM/HUAP 277/2011), active at the moment of the study development. This study presents no real or potential conflict of interest from the authors.

\section{RESULTS AND DISCUSSION}

During the data collection period, 79 patients were admitted to the Masculine and Feminine Medical Clinics. Twelve of them did not have any prior information (neither medical records nor reports from the patient and/or care giver) regarding the medication use, two patients refused to participate on this study and five were considered disoriented and unable to answer questions. So, 60 patients were included in the study: 32 females and 28 males, with an age average of 50.87 years $(\mathrm{SD}=14.37)$.

The most frequent comorbidities were hypertension (41.9\%), diabetes mellitus (17.4\%), lupus (3.5\%), chronic renal failure $(4,6 \%)$ and depression $(2.3 \%)$. Eleven patients $(18.3 \%)$ had some type of drug allergy. The drugs related to allergies were dipyrone $(20 \%)$, penicillin $(26.6 \%)$, gentamicin (6.6\%), iodine (20\%), sulfa (6.6\%), omeprazole $(6.6 \%)$, ranitidine $(6.6 \%)$ and vancomycin $(6.6 \%)$.

A total of 260 medicines were used previously to admission (Figure 1). Of those, $75.4 \%$ were kept in prescriptions during hospitalization, $18.45 \%$ were suspended, according to clinical judgment and decision of the physician responsible for the patient, and $6.15 \%$ represented omission errors.

The average of medications taken by patients before admission was $4.3(\mathrm{SD}=2.94)$. It is important to consider that this information may has a certain grade of imprecision since many patients did not know or remember exactly all the details about their previous medications. The major anatomical groups (ATC classification) were cardiovascular system (25\%), nervous system (22.5\%), alimentary tract and metabolism (20\%) (Table I). 
TABLE I - Percentage of use of each therapeutic group before and after hospitalization, Niteroi, 2012, N=260

\begin{tabular}{lclc}
\hline \multicolumn{1}{c}{ Before hospitalization } & \multicolumn{1}{c}{ After hospitalization } & Use (\%) \\
\hline ATC Group & Use (\%) & ATC Group & 21,42 \\
\hline Cardiovascular System (C) & 25,00 & Cardiovascular System (C) & 20,40 \\
Nervous System (N) & 22,50 & Alimentary Tract and Metabolism(A) & 16,32 \\
Alimentary Tract and Metabolism (A) & 20,00 & Nervous System (N) & 12,24 \\
Blood and Blood Forming Organs (B) & 8,75 & Antiinfectives for Systemic Use (J) & 10,20 \\
Antineoplastic and Immunomodulating Agents (L) & 5,00 & Blood and Blood Forming Organs (B) & 4,08 \\
Systemic Hormonal Preparations, excl. Sex & 3,75 & Systemic Hormonal Preparations, excl. Sex & 4,08 \\
hormones and Insulins (H) & \multicolumn{2}{c}{ hormones and Insulins (H) } & 4,08 \\
Musculo-Skeletal system (M) & 3,75 & Antineoplastic and Immunomodulating Agents (L) & 4,08 \\
Respiratory System (R) & 3,75 & Musculo-Skeletal System (M) & 2,04 \\
Antiinfectives for Systemic Use (J) & 2,50 & Respiratory System (R) & 1,02 \\
Antiparasitic Products, Insecticides and Repellents & 2,50 & Antiparasitic Products, Insecticides and Repellents & \\
(P) & \multicolumn{2}{l}{ (P) } & Various (V) \\
Genito Urinary System and Sex Hormones (G) & 1,25 & & \\
Various (V) & 1,25 & & \\
\hline
\end{tabular}

After admission, the average of medications per patient was 6.3 with emphasis on the following anatomic groups: cardiovascular system (21.4\%), alimentary tract and metabolism $(20.4 \%)$, nervous system $(16.3 \%)$ (Table I).

For 14 patients $(23,3 \%)$, at least one pharmaceutical intervention was necessary. This result is similar to that observed by Tjia and collaborators (2009), who found $21.3 \%$ medication discrepancies, but in a population of 199 patients. However, it is lower than the value observed in other studies. Gleason et al. (2011) found that 35.9\% of the patients had at least one discrepancy at transitions and clinical handoffs. Vira et al. (2006) found that $60 \%$ of the patient had at least one unintended variance and that $18 \%$ had at least one clinically important unintended variance. Franco-Donat et al. (2010) found that $42 \%$ of 102 patients submitted to a reconciliation process showed a drug related problem. Knez et al. (2011) found that $74.3 \%$ of in-patient therapy were in discordance with the patients' pre-admission therapy but most were intentional discrepancies and only $8.3 \%$ of them corresponded to drug errors. Hellstrom et al. (2012) found that at least one medication history error was identified by pharmacists conducting medication reconciliations in $47 \%$ of the patients. Becerra-Camargo et al. (2013) found that $93,6 \%$ of the patients had at least one admission discrepancy.

A total of 26 interventions (Table II) were made. None of the 26 errors observed were considered intentional. All the dose problems were related to the reconciliation process and not with doses out of the limits proposed at the literature. Table III illustrates some of the problems identified as well as the proposed intervention. It was observed a $90 \%$ level of acceptance of the interventions proposed by the pharmacy, which is in accordance with the results of Vira et al. (2006) and Hellstrom et al. (2012) that obtained $98 \%$ and $94 \%$ of physicians' acceptance, respectively. A lower acceptance level (48\%) was observed by Lubowski et al. (2007). The authors attribute that to the lack of time to solve drug-related problems.

TABLE II - Pharmaceutical Interventions, Niteroi, 2012, N=26

\begin{tabular}{lc}
\hline Intervention type & $\begin{array}{c}\text { Number of } \\
\text { occurrence }\end{array}$ \\
\hline Medication inclusion recommended & 16 \\
Dose adjustment (higher dose) & 1 \\
Dose adjustment (lower dose) & 2 \\
Medication discontinuation & 7 \\
\hline Total & $\mathbf{2 6}$ \\
\hline
\end{tabular}

Anti-hypertensives was the class of medication more frequently involved in medication errors $(20 \%)$, followed by antimalarial (10\%) and anti-anemic, antiemetic, antipsychotic, anti-allergic, anti-anxiety, anticoagulant, anti-vertigo, bone resorption inhibitor, vitamin, immunosuppressant, antilipemic and cardio tonics (representing 5\% of total each). Carvedilol (C07AG02) and hydroxychloroquine (P01BA02) were the drugs more 
TABLE III - Examples of Drug Related Problems Identified and interventions. Niterói, 2012

\begin{tabular}{ll}
\hline Identified Problem & Intervention \\
\hline $\begin{array}{l}\text { Patient was taking simvastatin } 20 \mathrm{mg} \text { before admission. There was neither } \\
\text { simvastatin or another drug in the same class or replacement. }\end{array}$ & $\begin{array}{l}\text { Physician was informed of the omission } \\
\text { and medicines included.. }\end{array}$ \\
\hline $\begin{array}{l}\text { Patient, who had systemic lupus erythematosus, three years on treatment, and } \\
\text { osteoporosis. The medications to treat these pathologies were not prescribed at } \\
\text { admission. }\end{array}$ & $\begin{array}{l}\text { Physician was informed of the omission } \\
\text { and medicines included. }\end{array}$ \\
\hline $\begin{array}{l}\text { Patients using hydroxychloroquine, azathioprine, flunarizine, haloperidol, } \\
\text { promethazine, digoxin, levothyroxine, and carvedilol prior to admission without } \\
\text { prescription at hospital admission. }\end{array}$ & $\begin{array}{l}\text { Physician was informed of the omission } \\
\text { and medicines included. }\end{array}$ \\
\hline $\begin{array}{l}\text { Patient using captopril } 25 \text { mg of } 8 \text { in } 8 \text { hours prior hospitalization. The dose was } \\
\text { doubled the admission prescription, with no history of hypertensive crisis or any } \\
\text { other medical condition that would justify dose modification. }\end{array}$ & $\begin{array}{l}\text { Physician was informed and the dose } \\
\text { adjusted. }\end{array}$ \\
\hline $\begin{array}{l}\text { Patient reported insomnia on the first night in the hospital, by making use of } \\
\text { tranquilizer at night, which was not communicated to the physician in the hospital. }\end{array}$ & $\begin{array}{l}\text { Physician was informed of the omission } \\
\text { and medicines included. }\end{array}$ \\
\hline $\begin{array}{l}\text { Patient was diagnosed with deep vein thrombosis and with anticoagulant indication } \\
\text { in the chart, however, the drug was not prescribed. }\end{array}$ & $\begin{array}{l}\text { Physician was informed of the omission } \\
\text { and medicines included. }\end{array}$ \\
\hline
\end{tabular}

often involved in pharmaceutical interventions $(8.7 \%$ each).

Omission was the main $(61.54 \%)$ category of errors identified, followed by dosing errors (11.54\%) and incorrect medication (3.85\%). According to the NCCMERP classification, the majority of the errors $(80 \%)$ was classified as B category (the error occurs, but does not reach the patient), followed by class $\mathrm{C}(15 \%)$ (the error reach the patient, but does not cause harm). Omission errors were also the most frequent problem identified by many authors (Lubowski et al., 2007; Pippins et al., 2008; Salanitro et al., 2012; Hellstrom et al., 2012). Dosing errors level is also in accordance with the literature (Pippins et al., 2008; Stone et al., 2010). The percentage of switched medications (4\%) was similar to that found by Hellstrom et al. (2012), who observed $5 \%$ of this problem.

Among the medication omissions, some situations call attention. A patient taking levothyroxine and other patient taking haloperidol, regularly before admission, have neither those medications, nor any other related prescribed after hospitalization. The suggestion of inclusion of the medications was promptly accepted by the physician.

Another case of great relevance was a patient who had systemic lupus erythematosus, three years on treatment, and osteoporosis but had neither record of the diseases, nor prescription drugs to treat them in their files. During the reconciliation an old prescription was discovered. Just then the physician was aware of the health problems and could prescribe the medication. Three cases of omission of antihypertensive drugs were found and immediately incorporated.

Another case that drew attention was a patient on erythropoietin $4000 \mathrm{IU}$, three times a week, regularly prescribed. Observing the records of the day before, it was found that the drug was not administered because it was not available at the hospital. Contacting the pharmacy service, it was observed that there was erythropoietin $10,000 \mathrm{IU}$ in stock, but to be released, it would be necessary a change in the prescription. The physician was contact, made the change and the patient could finally receive the medication he needed.

In our study, $75 \%$ of the problems identified could have led to damage to the patients if not identified. This result is in accordance with Vira et al. (2006), who considered that of the $20(18 \%)$ of clinically important variances found, $75 \%$ could have lead to patients' harm if not intercepted. However, other studies found a lower proportion of harm related to drug errors. BecerraCamargo et al. (2013) considered that only $42.7 \%$ of the errors could lead to a patient discomfort and Salanitro et al. (2012) pointed out that only $59 \%$ of the errors could result in harm for the patient.

There was no statistical significance between the number of medicines taken for each patient and the occurrence of drug related problems $(p=0.072)$. This result differs from the analysis of Lubowski et al. (2007), Gleason et al. (2011) and Hellstrom et al. (2012), but is in accordance with the results of Cornish et al. (2005). Patients' age has no statistical relationship with drug 
related problem $(\mathrm{p}=0,837)$, which is in accordance with the results of Hellstrom et al. (2012). However, Gleason et al. (2011) found a significant relationship between drug related problems and age $>65$ years.

A total of $53 \%$ of the interventions occurred with female patients. The gender showed a statistical significant relationship with drug related problems $(\mathrm{p}=0.013)$, differing from the results of Hellstrom et al. (2012), in which this parameter was not significant.

The Chi-square test showed that the period of hospitalization (day or night) and type of admission (elective or emergency), had no significant relation with the occurrence of drug related problems ( $\mathrm{p}$-values 0.133 and 0.532 , respectively), which is in accordance with the results of Gleason et al. (2011).

Despite the limited number of patients and short time of observation, important limitations of this study, it is possible to consider that the pharmacist participation in the medication reconciliation process has a potential to collaborate with a safer use of medicines. Other authors have pointed out this aspect (Vira et al., 2006; Lubowski et al., 2007; Cobaugh et al.,2008; Pippins et al., 2008; Coffey et al., 2009; Stone et al., 2010; Miranda et al., 2012; Chhabra et al., 2012; Haynes et al., 2012).

The possibility of identifying a drug related problem during admission reconciliation is directly related to patients' drug history. Some authors call attention to the difficulty of obtaining this information, the presence of incomplete data, to the inadequate communication and to the patients lack of understanding regarding their treatment. The importance of reliable drug history available before initiating reconciliation is also emphasized (Coffey et al., 2009; Salanitro et al., 2012). This aspect was particularly important in this study since it was observed constant lack of information in the medical records, which often diminished the reconciliation contribution to avoid drug related problems. In this study, it was observed a high level of patients' misinformation about the medicines they use. Twelve patients were admitted in the study period but the reconciliation was not possible because they were not able to inform any data on what they used before getting to the hospital. Also, there were no prescriptions with them. So, patients' medication history quality can also be considered one of the study limitations.

The small number of patients, the observation of only two clinics in a single health facility and the short follow-up time are the main limitations of the study, suggesting caution in extrapolating the results to other health facilities. However, the study showed both the relevance as the feasibility of incorporating reconciliation in hospital routine. Unfortunately, the activity was not included in the pharmacists' routine because of the lack of human resources.

\section{REFERENCES}

AMERICAN SOCIETY OF HEALTH SYSTEM PHARMACISTS. AHFS drug information 2012. Bethesda: American Society of Health System Pharmacists, 2012. p.4000.

BECERRA-CAMARGO, J.; MARTINEZ-MARTINEZ, F.; GARCIA-JIMENEZ, E. A multicentre, doubleblind, randomised, controlled, parallel-group study of the effectiveness of a pharmacist-acquired medication history in an emergency department. BMC Health Serv. Res., v.13, n.337, p.1-12, 2013.

BOOCKVAR, K.S.; BLUM, S.; KUGLER, A.; LIVOTE, E.; MERGENHAGEN, K.A.; NEBEKER, J.R.; SIGNOR, D.; SUNG, S.; YEH, J. Effect of admission medication reconciliation on adverse drug events from admission medication changes. Arch. Intern. Med., v.171, n.9, p.860861, 2011.

CALL, R.J.; BURLISON, J.D.; ROBERTSON, J.J.; SCOTT, J.R.; BAKER, D.K.; ROSSI, M.G.; HOWARD, S.C.; HOFFMAN, J.M. Adverse drug event detection in pediatric oncology and hematology patients: using medication triggers to identify patient harm in a specialized pediatric patient population. J. Pediatrics, v.165, n.3, p.447-452, 2014.

CHAMBERS, J.D.; THORAT, T.; PYO, J.; CHENOWETH, M.; NEWMANN, P.J. Despite high costs, specialty drugs may offer value for money comparable to that of traditional drugs. Health Aff., v.33, n.10, p.1751-1760, 2014.

CHHABRA, P.T.; RATTINGER, G.B.; DUTCHER, S.K.; HARE, M.E.; PARSONS, K.L.; ZUCKERMAN, I.H. Medication reconciliation during the transition to and from long-term care settings: a systematic review research in social and administrative pharmacy. Res. Social Adm. Pharm., v.8, p.60-75, 2012.

COBAUGH, D.J.; ALMIR, A.; BOOKWALTER, T.; WILLIAMS, M.; GRUNVALD, P.; LACIVITA, C.; HAWTEINS, B. ASHP - SHM joint statement on hospitalist - pharmacist collaboration. Am. J. Health-Syst. Pharm., v.65, p.260-263, 2008. 
COFFEY, M.; CORNISH, P.; KOONTHANAM, T.; ETCHELLS, E.; MATLOW, A. Implementation of admission medication reconciliation at two academic health sciences centres: challenges and success factors. Healthc. Q., v.12, sp.iss., p.102-109, 2009.

CORNISH, P.L.; KNOWLES, S.R.; MARCHESANO, R.; TAM, V.; SHADOWITZ, S.J.; URLINK, D.N.; ETCHELLS, E.E. Unintended medication discrepancies at the time of hospital admission. Arch. Intern. Med., v.165, n.4, p.424-429, 2005.

DIAS, M.A.E.; MARTINS, M.; NAVARRO, N. Rastreamento de resultados adversos nas internações do Sistema Único de Saúde. Rev. Saúde Pública, v.46, n.4, p.719-729, 2012.

FRANCO-DONAT, M.; SOLER-COMPANY, E.; VALVERDE-MORDT, C.; GARCIA-MUÑOZ, S.; ROCHER-MILLA, A.; SANGUESA-NEBOT, M.J. Conciliación de la medicación al ingresso y al alta hospitalaria em um servicio de cirurgia ortopédica y traumatologia. Rev. Esp. Cir. Ortop. Traumatol., v.54, n.3, p.149-155, 2010.

GALLOTTI, R.M.D. Eventos adversos e óbitos hospitalares em serviço de emergências clínicas de um hospital universitário terciário: um olhar para a qualidade da atenção. São Paulo, 2003. 148 p. [Thesis of PhD degree. Faculty of Pharmaceutical Sciences. University of São Paulo].

GIORDANI, F.; ROZENFELD, S.; OLIVEIRA, D.F.M.; VERSA, G.L.G.S.; TERENCIO, J.S.; CALDEIRA, L.F. Vigilância de eventos adversos a medicamentos em hospitais: aplicação e desempenho de rastreadores. Rev. Bras. Epidemiol., v.15, n.3, p.455-467, 2012.

GIORDANI, F.; ROZENFELD, S. Adverse drug events in hospitals: a systematic review. Cad. Saúde Pública, v.25, n.3, suppl.3, p.360-372, 2009.

GLEASON, K.M.; MCDANIEL, M.R.; FEINGLASS, J.; BAKER, D.W.; LINDQUIST, L.; LISS, D.; NOSKIN, G.A. Results of medications at transitions and clinical handoffs (MATCH) study: an analysis of medication reconciliation errors and risk factors at hospital admission. J. Gen. Intern. Med., v.25, n.5, p.441-447, 2011.

GOTTLIEB, S. Drug safety proposals and the intrusion of federal regulation into patient freedom and medical practice. Health Aff., v.26, n.3, p.664-677, 2007.
HARTWIG, S.C.; DENGER, S.D.; SCHNEIDER, P.J. Severityindexed, incident report-based medication error-reporting program. Am. J. Hosp. Pharm., v.48, p.2611-2616, 1991.

HAYNES, K.T.; OBERNE, A.; CAWTHON, C.; KRIPALANI, $\mathrm{S}$. Pharmacists' recommendations to improve care transitions. Ann. Pharmacother., v.46, n.9, p.1152-1159, 2012.

HELLSTROM, L.M.; BONDESSON, A.; HOGLUND, P.; ERIKSSON, T. Errors in medication history at hospital admission: prevalence and predicting factors. BMC Clin. Pharmacol., v.12, n.9, p.1-9, 2012.

KOHN, L.T.; CORRIGAN, J.M.; DONALDSON, M.S. To Err is human: building a safer health system. Washington: Committee on Quality of Health Care in America, National Academy of Institute of Medicine, 2001. p.312.

KNEZ, L.; SUSKOVIC, S.; REZONJA, R.; LAAKSONEN, R.; MRHAR, A. The need for medication reconciliation: a cross-sectional observational study in adult patients. Resp. Med., v.105, suppl.1, p.S60-S66, 2011.

LEAPE, L.L.; BRENNAN, T.A.; LAIRD, N.L. The nature of adverse events and negligence in hospitalized patients: results of the Harvard medical practice study II. New Engl. J. Med., v.324, n.6, p.377-384, 1991.

LUBOWSKI, T.J.; CRONIN, L.M.; PAVELKA, R.W.; B R I S COE-DWYER, L.A.; BRICELAN, L.L.; HAMILTON, R.A. Effectiveness of a medication reconciliation project conducted by pharmD students. Am. J. Pharm. Educ., v.71, n.5, art.94, p.1-7, 2007.

MARQUES, T.C.; REIS, A.M.M.; SILVA, A.E.B.C.S.; GIMENES, F.R.E.; OPITZ, S.P.; TEIXEIRA, T.C.A.; LIMA, R.E.F.; CASSIANI, S.H.B. Erros de administração de antimicrobianos identificados em estudo multicêntrico brasileiro. Re. Bras. Cienc. Farm., v.44, n.2, p.305-314, 2008.

MENDES, W.; PAVÃO, A.L.B.; MARTINS, M.; MOURA, M.L.O.; TRAVASSOS, C. Características de eventos adversos evitáveis em hospitais do Rio de Janeiro. Rev. Assoc. Med. Bras., v.59, n.5, p.421-428, 2013.

MENDES, W.; TRAVASSOS, C.; MARTINS, M.; MARQUES, P.M. Adaptação dos instrumentos de avaliação de eventos adversos para uso em hospitais brasileiros. Rev. Bras. Epidemiol., v.11, n.1, p.55-56, 2008. 
MIRANDA, M.M.T.; PETRICCIONE, S.; FERRACINI, T.F.; BORGES FILHO, W.M. Interventions performed by the clinical pharmacist in the emergency department. Einstein, v.10, n.1, p.74-78, 2012.

MORAN, J.; SCANLON, D. Slow progress on meeting hospital safety standards: learning from the Leapfrog Group's efforts. Health Aff., v.32, n.1, p.27-35, 2013.

NCCMERP (National Coordinating Council for Medication Error Reporting and Prevention). About medications errors. Available at: $<$ http://www.nccmerp.org/about-medicationerrors>. Accessed on: 04 Nov. 2012.

OTERO, M.J.; MARTÍN, R.; ROBLES, M.D.; COLINA, C. Errores de medicación. In: Farmacia hospitalaria. Espanha: Sociedad Española de Farmácia Hospitalaria, 2002. v.747, cap.2.14, p.714-747.

PIPPINS, J.R.; GANDHI, T.K.; HAMANN, C.; NDUMELE, C.D.; LABONVILLE, S.A.; DIEDRICHSEN, E.K. Classifying and predicting errors of inpatient medication reconciliation. J. Gen. Intern. Med., v.23, n.9, p.1414-1422, 2008 .

REIS, A.M.M.; CASSIANI, S.H.B. Prevalence of potential drug interactions in patients in an intensive care unit of a university hospital in Brazil. Clinics, v.66, n.1, p.9-15, 2011.

ROQUE, K.E.; MELO, E.C.P. Avaliação dos eventos adversos a medicamentos no contexto hospitalar. Esc. Anna Nery, v.16, n.1, p.121-127, 2012.

ROSA, M.B.; PERINI, E. Erros de medicação: quem foi? Rev. Ass. Med. Brasil., v.49, n.3, p.335-341, 2003.

ROZENFELD, S.; GIORDANI, F.; COELHO, S. Adverse drug events in hospital: pilot study with trigger tool. Rev. Saúde Pública, v.47, n.6, p.1-9, 2013.

ROZENFELD, S.; CHAVES, S.M.; REIS, L.G.; MARTINS, M.; TRAVASSOS, C.; MENDES, W. Adverse effects from drugs in a public hospital: pilot study. Rev. Saúde Publica, v.43, n.5, p.887-890, 2009.

SALANITRO, A.H.; OSBORN, C.Y.; SCHNIPPER, J.L.; ROUMIE, C.L.; LABONVILLE, S.; JOHNSON, D.C.; NEAL, E.; CAWTHON, C.; BUSINGER, A.; DALAL, A.K.; KRIPALANI, S. Effect of patient - and medication related factors on inpatient medication reconciliation errors. J. Gen. Intern. Med., v.27, n.8, p.924-932, 2012.
SANTOS, G.E.O. Cálculo amostral: calculadora on-line. Available at: $<$ http://www.calculoamostral.vai.la. Access in: Jan. 20, 2012.

SMITH, M.A.L.; RUIZ, I.A.; JIRON, M.A. Errores de medicación en el Servicio de Medicina de un hospital de alta complejidad. Rev. Méd. Chile, v.142, n.1, p.40-47, 2014.

STONE, B.L.; BOEHME, S.; MUNDORFF, M.B.; MALONEY, C.G.; SRIVASTAVA, R. Hospital admission medication reconciliation in medically complex children: an observational study. Arch. Dis. Child., n.95, p.250-255, 2010.

THOMSON, DRUGDEX ${ }^{\circledR}$ System. Thomson MICROMEDEX. 2012 Available at: <http://www.micromedexsolutions.com/ micromedex $2 /$ librarian?partner $=$ true $>$. Accessed on: 16 Nov. 2012.

TJIA, J.; BONNER, A.; BRIESACHER, B.A.; MCGEE, S.; TERRILL, E.; MILLER, K. Medication discrepancies upon hospital to skilled nursing facility transitions. J. Gen. Intern. Med., v.24, p.630-635, 2009.

VENTURA, C.M.U.; ALVES, J.G.B.; MENESES, J.A. Eventos adversos em Unidade de Terapia Intensiva Neonatal. Rev. Bras. Enferm., v.65, n.1, p.49-55, 2012.

VIRA, T.; COLQUHOUN, M.; ETCHELLS, E. Reconcilable differences: correcting medication errors at hospital admission and discharge. Qual. Saf. Health Care, v.15, n.2, p.122-126, 2006.

WHO (World Health Organization). Assuring medication Accuracy at Transitions in Care. Patient Safety Solutions, v.1, sol.6, p.1-4, 2007. Available at: <http:/www.who.int/ patientsafety/solutions/patientsafety/PS-Solution6.pdf $>$. Accessed on: Nov. 2012.

Received for publication on $19^{\text {th }}$ November 2014 Accepted for publication on $13^{\text {th }}$ January 2016 